\title{
KARDYNAŁA KAROLA WOJTYŁY KONCEPCJA CZłOWIEKA
}

Kardynał Karol Wojtyła to dla większości z nas po prostu Jan Paweł II, papież, natomiast bardzo mało osób poznało go jako filozofa. Istnieje niebezpieczeństwo, że wraz z upływającym czasem po śmierci papieża filozofia K. Wojtyły może zostać zapomniana, a przecież właśnie to filozoficzne zaplecze stało u podstaw wielu ważnych wypowiedzi Jana Pawła II.

W swych filozoficznych poszukiwaniach Wojtyła korzysta z dwóch optyk: ontologii oraz fenomenologii ${ }^{1}$. Tworzy on nie tylko bardzo płodną syntezę, łączącą w sobie zarówno to, co jest obiektywnym porządkiem rzeczy opisywanym z punktu widzenia metafizyki arystotelesowsko-tomistycznej, jak i to, co wynika bezpośrednio z doświadczenia człowieka na drodze fenomenologicznej; lecz dość oryginalną, protagonistyczną antropologię, której nie zdołał jednak w pełni uformować. Najpełniejszy obraz personalistycznej metafizyki Wojtyły możemy ujrzeć w najdojrzalszym dziele, jakim jest Osoba i czyn. Trzeba przy tym przyznać, że filozofia Wojtyły nie daje się łatwo oswoić niewprawnemu czytelnikowi.

*Andrzej Jastrzębski OMI, mgr teologii PWT Poznań 1999, dr filozofii KUL 2006 (specjalizacja - metafizyka i antropologia filozoficzna), Asystent Wykonawczy Rady Generalnej Misjonarzy Oblatów Maryi Niepokalanej - Rzym.

${ }^{1}$ Por. S. Kamiński, Jak filozofować o człowieku, Analecta Cracoviensia 1973-1974, t. $5-6$, s. 78.

${ }^{2}$ Por. J. Tischner, Metodologiczna strona dzieta "Osoba i czyn", Analecta Cracoviensia 1973-1974, t. 5-6, s. 85. 
Oryginalność ujęcia Wojtyły polega na tym, że ukazał dynamikę działania człowieka jako osoby kierującej się prawdą i kształtującej się poprzez moralną wartość tych działań, dochodząc w ten sposób do wypracowania teorii samostanowienia. Najbardziej modne współczesne kierunki filozofii skupiają się na tym, co podpada pod analizę semantyczną, nie docierając do podstaw bytowych faktu ludzkiego ${ }^{3}$. W celu założenia dobrego fundamentu swej antropologii Wojtyła przeprowadza reinterpretację Kartezjańskiego cogito. Uznając moment świadomości, zachowuje istotną funkcję poznania (samowiedzy podmiotu), którego jednak nie opiera na świadomości ${ }^{4}$. Co więcej, wskazując na to, że człowiek jest współtwórcą siebie poprzez strukturę samostanowienia pod względem moralnym, Wojtyła zwalcza współczesne dążenie człowieka do absolutnej autonomii moralnej (swawoli) . $^{5}$

Filozofię Wojtyły można by nazwać personalizmem czy nowatorską antropologią zbudowaną na analizach filozoficznych, które odnoszą się jednocześnie do kilku klasycznych dziedzin filozofii: metafizyki, teorii poznania, etyki, teorii świadomości oraz w końcu psychologii i medycyny. Ukazuje też istotną rolę istnienia w strukturze bytu ludzkiego, choć intuicji tej nie rozwija i stąd jego analizy nie mogą być ostatecznie uznane za egzystencjalne, a raczej za esencjalistyczne ${ }^{6}$.

\section{WEWNĘTRZNY DYNAMIZM OSOBY}

Wojtyła, przeprowadzając wgląd w człowieka, wskazuje w pierwszej linii analizy fenomenologicznej na dwa poziomy zdynamizowania osoby ludzkiej:

- poziom wegetatywny, który charakteryzuje się mniejszym lub większym stopniem nieuświadomienia (np. bicie serca) ${ }^{7}$,

- poziom przeżycia, w którym człowiek doświadcza tego, że „,ja działam"

Na tym drugim poziomie spotykamy już świadomość, która jawi się jako podstawa odzwierciedlania dynamizmu w osobie, jako czynnik, który umożliwia przeżywanie i doświadczanie dynamizmu. Fakt ten w zasadniczy sposób odróżnia dynamizm wegetatywny od dynamizmu przeżywanego.

${ }^{3}$ Por. J. Galarowicz, Człowiek jest osobq. (Podstawy antropologii filozoficznej Karola Wojtyły), Kraków 1994, s. 218.

${ }^{4}$ R. Buttiglione, Myśl Karola Wojtyty, Lublin 1996, s. 397.

${ }^{5}$ Por. J. Galarowicz, Człowiek jest osobq, s. 219.

${ }^{6}$ M. Gogacz, Wokót problemu osoby, Warszawa 1974, s. 108, 116.

${ }^{7}$ Por. J. Galarowicz, Imię wtasne człowieka. (Klucz do myśli i nauczania Karola Wojtyty - Jana Pawła II), Kraków 1996, s. 124.

${ }^{8} \mathrm{~K}$. Wojtyła, Osoba i czyn, w: tenże, Osoba i czyn oraz inne studia antropologiczne, Lublin 1994, s. 109n. Por. S. Grygiel, Hermeneutyka czynu oraz nowy model świadomości, Analecta Cracoviensia 1973-1974, t. 5-6, s. 146. 
Między działaniem człowieka a tym, co tylko dzieje się w człowieku, zachodzi pewna różnica, przeciwstawność, która wypływa z kryterium świadomości ${ }^{9}$, a także - jak to później zobaczymy - ze sprawczości. Te dwa dynamizmy bytu ludzkiego mają jednak coś wspólnego - jest to człowiek jako podmiot wszelkiego dynamizmu ${ }^{10}$. W nim, a ściślej w jego bytowości, odnajdujemy wspólne korzenie, to znaczy jedno podłoże istnienia dla obu dynamizmów człowieka.

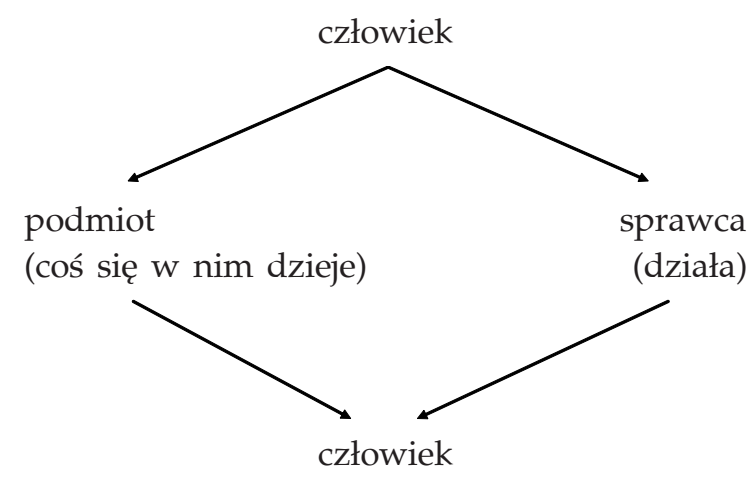

podmiot jako byt - podmiot zdynamizowany

podłoże = suppositum ${ }^{11}$

W suppositum odnajdujemy właśnie punkt, w którym łączy się i to, co tylko dzieje się w człowieku, i to, co człowiek świadomie czyni. Inaczej mielibyśmy do czynienia z dramatem wewnętrznego podziału człowieka - z jakąś schizofrenią.

W filozofii klasycznej spotykamy podział na actus humanus i actus hominis. Wojtyła określa ten podział jako nieprecyzyjny, ponieważ każdy czyn ludzki (actus humanus) jest zarazem czynem człowieka (actus hominis). Tym, co pozwala nam uwyraźnić znaczenie obu pojęć, jest moment sprawczości, który określamy jako przeżycie tego faktu, że ,jestem sprawcą", że ,jestem przyczyną" swego działania. W ten sposób actus hominis zakłada actus humanus, każdy świadomy czyn angażuje przecież całego człowieka, a nie tylko jego sferę duchową.

Istota sprawczości leży w tym, że osobowe ,ja” aktualizuje się (używając terminologii metafizycznej) w czynie, który wskutek tej sprawczości staje się własnością osoby. Człowiek jest zatem w jakiś sposób obecny w swym dzia-

${ }^{9}$ R. Buttiglione, Kilka uwag o sposobie czytania "Osoby i czynu”, w: K. Wojtyła, Osoba i czyn, s. 19.

${ }^{10} \mathrm{~K}$. Wojtyła, Osoba i czyn, s. 112.

${ }^{11}$ Por. J. Galarowicz, Imię własne człowieka, s. 125. 
łaniu, a przez to rodzi się też odpowiedzialność za każdy czyn, którego jest świadomym sprawcą ${ }^{12}$.

Człowiek jest w swym działaniu równocześnie immanentny (jako ,ja działające") i transcendentny (poprzez przeżycie sprawczości) ${ }^{13}$. Synteza tych dwóch wymiarów w osobie prowadzi do osiągnięcia jedności osoby z czynem w człowieku ${ }^{14}$, jedności nie statycznej, lecz dynamicznej ${ }^{15}$.

Przeżycie sprawczości, które dostrzegamy u człowieka, jawi się nam zatem jako podstawowe kryterium, dzięki któremu możemy dokonywać różnicowania w osobie tego, co jest w niej elementem biernym - samym tylko uczynnieniem natury, a tym, co faktycznie jest aktem osoby - czyli jej czynem ${ }^{16}$.

Istotą sprawczości jest wywołanie zaistnienia i istnienie skutku w przeciwieństwie do twórczości, gdzie istotą jest ukształtowanie dzieła17, a nie jego zawartość ukazująca dynamikę osoby i rodząca odpowiedzialność. Człowiek - a szczególnie jego wartość moralna - jest pierwszym tworzywem własnej sprawczości (twórczości). Można to przedstawić w ten sposób:

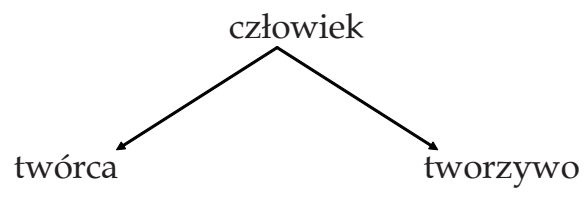

Podział, który przedstawiłem powyżej, wypływa z wewnętrznego doświadczenia człowieka. Dochodzimy do tego, że istnienie (byt) ujawnia się jako podstawa tak strony pasywnej, jak i aktywnej w człowieku ${ }^{18}$.

Idąc dalej, osoba ukazuje się nam z jednej strony jako podmiot, który działa (ktoś), a z drugiej strony jako przedmiot działania (coś). W człowieku jednakże istnienie i działanie są osobowe, a spotykają się jako synteza dynamizmu operari i esse we wspólnym bytowym suppositum ${ }^{19}$.

${ }^{12}$ K. Wojtyła, Osoba $i$ czyn, s. 115n.

${ }^{13} \mathrm{~J}$. Galarowicz, Imię wtasne człowieka, s. $125 \mathrm{n}$.

${ }^{14}$ K. Wojtyła, Osoba i czyn, s. 117.

${ }^{15}$ Por. tamże, s. 242.

${ }^{16}$ Tamże, s. 118.

17 Tamże, s. 119.

${ }^{18}$ Tamże, s. 120.

${ }^{19}$ Tamże, s. 121n. Por. M. Jaworski, Koncepcja antropologii filozoficznej w ujęciu Kard. Karola Wojtyty. (Próba odczytania w oparciu o studium "Osoba $i$ czyn"), Analecta Cracoviensia 1973-1974, t. 5-6, s. 102. 
Możemy więc powiedzieć tak: „Struktury 'człowiek działa' oraz '(coś) dzieje się w człowieku' przecinają pole fenomenologiczne doświadczenia, natomiast $\mathrm{w}$ polu metafizycznym zespalają się i jednoczą. Człowiek-osoba stanowi ich syntezę, ostateczny zaś podmiot tej syntezy określamy jako suppositum"20.

Trzeba też wskazać na to, że suppositum odpowiada pojęcie natury jako określenie podmiotu (podstawy) działania ${ }^{21}$. Natura jest tym, co ma się narodzić w samym fakcie narodzin jako jego możliwa konsekwencja. Wskazuje ona (natura) na dynamiczną gotowość, po pierwsze, podmiotu do uczynnienia, a po drugie, osoby do czynu i stanowi zarazem czynnik integrujący dla nich obu ${ }^{22}$.

\section{SPRAWCZOŚĆ OSOBY A PRZYCZYNOWANIE NATURY}

W punkcie pierwszym wskazaliśmy na dwa rodzaje zdynamizowań obecnych w człowieku jako suppositum. Spróbujmy teraz scharakteryzować jeszcze dokładniej te dwie domeny, wskazując przy tym stosowne różnice. Jako podstawę naszej analizy obierzmy osobę, która (w sensie suppositum) jest podstawą uczynnień (aktów wegetatywnych, organicznych), które się w niej dzieją ${ }^{23}$, oraz czynów, które spełnia jako ich sprawca. W ten sposób osoba staje się zasadą jedności oraz tożsamości czynów i uczynnieńn ${ }^{24}$.

Tym, co pozwala odróżnić to, co dzieje się w człowieku, od tego, co on rzeczywiście czyni, jest moment sprawczości ${ }^{25}$. Jak wiadomo, uczynnienia należą do obszaru, który nie jest i nie może być kontrolowany przez świadomość. Może on być jedynie w jakiś sposób obserwowany. Stąd nie można mówić, że osoba kieruje poziomem somatyczno-wegetatywnym, a co za tym idzie, nie można mówić w tym miejscu o czynie człowieka.

Zupełnie odwrotnie rzecz się ma z świadomym działaniem człowieka. Tutaj świadomość oraz sprawczość są w akcie lub przynajmniej w jakiejś możliwości. Wszystko to zaś odbywa się dzięki strukturom samoposiadnia oraz samopanowania ${ }^{26}$. Dlatego sama osoba poprzez swe świadome działanie jako osobowe i uświadomione ,ja" jest podstawą:

${ }^{20}$ K. Wojtyła, Osoba i czyn, s. 124.

${ }^{21}$ Tamże, s. 125.

22 Tamże, s. 127.

${ }^{23}$ A. Półtawski, Epistemologiczne podstawy filozofii Karola Wojtyły, w: A. Pelczar, W. Stróżewski (red.), Servo veritatis II. (Spotkanie naukowe poświęcone myśli Jana Pawła II), Kraków 1996, s. 95.

${ }^{24}$ M. Jędraszewski, Filozofia i modlitwa, Poznań 1986, s. 202.

${ }^{25}$ Por. K. Wojtyła, Osoba i czyn, s. 116.

${ }^{26}$ Tenże, Osobowa struktura samostanowienia, w: tenże, Osoba i czyn, s. 429. 
- przeżycia sprawczości ${ }^{27}$,

- przeżycia tożsamości (wynika to z doświadczenia swego ,ja” przeżywającego swe czyny $)^{28}$.

Dzięki kategorii przeżycia zachodzi integracja natury oraz osoby ${ }^{29}$, które łączą się w jednym bytowym suppositum poprzez wprowadzenie uczynnień człowieka w proces samorealizacji osoby (intelekt i wola) ${ }^{30}$. Mamy więc jeden podmiot - „człowiek”, który jest osobą - suppositum, pewną jednością ${ }^{31}$, ale dwa rodzaje przyczynowania: naturę (uczynnienia) oraz osobę (akty) ${ }^{32}$.

Oba rodzaje przyczynowania mają charakter aktu³, oba są pewnym działaniem podmiotu, ale już nie w pełni osoby, jeśli przyjmiemy kryterium świadomości. Instynkt scala i ukierunkowuje to, co tylko się dzieje w podmiocie (tak jest w przypadku zwierząt). Nie można mówić w takim przypadku o samostanowieniu. Mamy tu do czynienia raczej z koniecznością, która zawarta jest już implicite w samym dynamizmie natury. Popycha ona co prawda ku jakimś określonym działaniom, ale bez jakiejkolwiek alternatywy działania odmiennego od tego, które w naturalnym dynamizmie jest zawarte. Instynkt możemy porównać ze samostanowieniem:

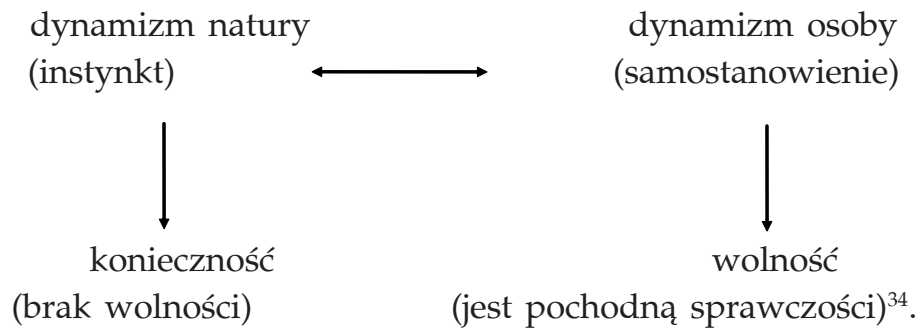

Z kolei działanie człowieka-osoby to przede wszystkim ta postać ludzkiego operari, jaką jest „czyn”. Chodzi tutaj o świadome działanie, w którym możemy też odczytać charakterystyczny dla człowieka rys wolności ${ }^{35}$.

${ }^{27}$ Por. tenże, Osoba $i$ czyn, s. 229.

${ }_{28}$ Tenże, Osobowa struktura samostanowienia, s. 439.

${ }^{29}$ Tenże, Osoba $i$ czyn, s. 128. Por. J. Gałkowski, Natura, osoba, wolność, Analecta Cracoviensia 1973-1974, t. 5-6, s. 179.

${ }^{30}$ R. Buttiglione, Myśl Karola Wojtyty, s. 229.

${ }^{31}$ Por. K. Wojtyła, Osoba i czyn, s. 237.

32 Tamże, s. 129n. Por. A. Forycki, Antropologia w ujęciu Kard. Karola Wojtyty, Analecta Cracoviensia $1973-1974$, t. 5-6, s. 229.

${ }^{33}$ J. Galarowicz, Imie własne człowieka, s. 125.

${ }^{34}$ K. Wojtyła, Osoba i czyn, s. 162n.

${ }^{35}$ Tenże, Osoba: podmiot $i$ wspólnota, w: tenże, Osoba i czyn, s. 379. 


\section{OPERARI SEQUITUR ESSE}

Prostą konsekwencją refleksji Wojtyły w odniesieniu do bytowego suppositum jest ukazanie fundamentalnej prawdy o ludzkim bycie. Jest on najpierw bytem istniejącym, a dopiero wtórnie działającym ${ }^{36}$. Choć zgodnie z porządkiem poznawczym z istnienia realności czynu wnioskujemy o istnieniu podmiotu, to jednak sam porządek ontyczny jest odwrotny - esse jest pierwotniejsze od operari $^{37}$.

Wojtyła nawiązuje tu do tradycyjnych zasad podanych przez św. Tomasza $^{38}$, który rozdziela istotę od istnienia, wskazując jednocześnie na jego przygodnośćc ${ }^{39}$. Istnienie zajmuje miejsce uprzywilejowane wobec działania tzn. wyprzedza je jako pierwotniejsze (pierwsze) ${ }^{40}$. Wszelkie dynamizmy, które zachodzą w człowieku jako podmiocie, są wtórne wobec pierwotnego zdynamizowania osoby jak bytu - aktualności istnienia, czyli esse $e^{41}$.

Według klasycznej metafizyki natura zawiera się w osobie (istocie) ${ }^{42}$. „Natura w ujęciu metafizycznym jest poniekąd tym samym co istota, tak więc w człowieku natura to tyle co całe 'człowieczeństwo' - jednakże nie 'człowieczeństwo' statyczne, ale dynamiczne: człowieczeństwo jako podstawa całego dynamizmu właściwego człowiekowi" ${ }^{43}$.

Operari sequitur esse i trzeba się z tym zgodzić, ponieważ istnienie działania zależy od istnienia człowieka per accidens - jest jakby jego przypadłością. Podstawą wszelkich działań jest więc natura (człowieczeństwo), która przenika w cały dynamizm człowieka: „....natura to podstawa istotowej spójności pomiędzy podmiotem dynamizmu a całym dynamizmem tego podmiotu"44.

${ }^{36}$ J. Galarowicz, Cztowiek jest osoba, s. 217.

${ }^{37}$ T. Rostworowski, Zagadnienie poznania w pracy Kard. Karola Wojtyty "Osoba i czyn", Rocznik Wydziału Filozoficznego Towarzystwa Jezusowego w Krakowie 1988, s. 126n.

${ }^{38}$ K. Wojtyła, Znak, któremu sprzeciwiać się będą, Poznań-Warszawa 1976, s. 18.

${ }^{39}$ J. Seifert, Die Person, mehr als die Substanz, als "eigentlich Seiendes", Karol Wojtyta und die Notwendigkeit einer neuen und zugleich klassischen, personalistischen Metaphysik, w: Servo veritatis, s. 55n.: „Nun lässt sich kaum bestreiten, dass im Vergleich zu jenen Attributen des Seins, die notwendig einem anderen Seienden inhärieren müssen und ontisch unselbständig sind, weil sich von diesem abhangen, die Substanz das im eigentlichen Sinne Seiende ist". Por. W. Stróżewski, O przygodności człowieka, w: J. P. Szczurek, R. Zawadzki (red.), Sympozjum naukowe z okazji 15-lecia pontyfikatu Jana Pawła II (Kraków, 11-12 X 1993), Kraków 1994, s. 45.

${ }^{40} \mathrm{~K}$. Wojtyła, Teoria - praxis: Temat ogólnoludzki i chrześcijański, w: tenże, Osoba i czyn, s. 469 .

${ }^{41}$ A. Wójtowicz, Osoba i transcendencja. (Karola Wojtyty antropologia wiary i Kościoła), Wrocław 1993, s. 153.

${ }^{42}$ K. Wojtyła, Osoba: podmiot i wspólnota, s. 378.

${ }^{43}$ Tenże, Osoba i czyn, s. 130.

${ }^{44}$ Tamże, s. 131. 
Idziemy teraz dalej i pytamy o sposób istnienia człowieka. Jest on osobą i właśnie ten fakt wpływa na to, że również jego istnienie ma charakter osobowy. Z tego z kolei wynika, że i wszelkie dynamizmy w człowieku, będąc związane z człowieczeństwem (naturą i podmiotem) ${ }^{45}$, są też realnie osobowe ${ }^{46}$. Nie ma miejsca dla rzetelnej afirmacji człowieka (podmiotu) bez uznania faktu jego istnienia ${ }^{47}$ oraz prawa do istnienia.

Przyjęcie osobowego charakteru całego dynamizmu człowieka jest bardzo ważnym wnioskiem, dzięki któremu nie musimy wykluczać z pola osoby tego, co się w niej tylko dzieje, ponieważ, „charakter osobowy ma nie tylko działanie, ale i dzianie się, oba te dynamizmy bowiem stanowią implikację osobowego istnienia (esse) człowieka" ${ }^{\prime 4}$.

Inaczej ujmując to zagadnienie, można stwierdzić, że rozumienie człowieka jako podmiotu działającego i jako wartości (jako daru) zakłada już uprzednio istniejącą ontologiczną strukturę osoby. Tak więc aksjologiczne rozumienie człowieka musi być poprzedzone rozumieniem ontologicznym ${ }^{49}$.

Posługując się zasadami tomistycznymi - szczególnie rozdzieleniem istoty $\mathrm{i}$ istnienia, osoby oraz istnienia, możemy stwierdzić, że cały dynamizm jest zintegrowany $\mathrm{w}$ osobie ${ }^{50}$, a podstawowym elementem, który łączy dwa dynamizmy, analizowane w poprzednich punktach, jest samo istnienie (esse). Analiza operari wiedzie zatem ku odkryciu ludzkiego esse $e^{51}$. Aby być osobą, trzeba najpierw po prostu być! ${ }^{52}$

\section{POTENCJALNOŚĆ I PODŚWIADOMOŚĆ}

Integracja dynamizmu w osobie nie znosi różnicy między czynem a uczynnieniem. Czynnikiem, który dzieli dwa wyżej wymienione obszary w osobie, jest niewątpliwie świadomość. To dzięki niej człowiek bytuje w pełni podmiotowo, dzięki niej również przeżywa siebie jako podmiot ${ }^{53}$.

Najbardziej wyraźne odzwierciedlenie w świadomości, czyli uświadomienie, uzyskują zdynamizowania potencjalności psycho-emotywnej, z drugiej stro-

${ }^{45}$ L. Wciórka, Filozofia człowieka, Warszawa 1982, s. 119.

${ }^{46}$ K. Wojtyła, Osoba i czyn, s. 132.

${ }^{47}$ T. Styczeń, Kard. Karol Wojtyta - filozof moralista, Roczniki Filozoficzne 1979, t. 27, z. 2, s. 27. Por. M. Gogacz, Hermeneutyka "Osoby i czynu”. (Recenzja ksiażki Kardynała Karola Wojtyty „Osoba i czyn”, Kraków 1969), Analecta Cracoviensia 1973-1974, t. 5-6, s. 132.

${ }^{48}$ J. Galarowicz, Człowiek jest osobq, s. 189.

${ }^{49}$ Por. tenże, Imię wtasne człowieka, s. 106.

${ }^{50}$ K. Wojtyła, Osoba i czyn, s. 132.

${ }^{51} \mathrm{~J}$. Dec, Podmiotowość osoby w ujęciu Kard. Karola Wojtyty. Z filozoficznego "zaplecza" encyklik Jana Pawła II, Colloquium Salutis 1983, t. 15, s. 183.

${ }^{52}$ A. Wójtowicz, Osoba i transcendencja, s. 154.

${ }^{53}$ Por. K. Wojtyła, Osoba: podmiot $i$ wspólnota, s. 387. 
ny zdynamizowania potencjalności somatyczno-wegetatywnej, a więc cała praca organizmu człowieka, wykazują o wiele mniejszy próg uświadomienia ${ }^{54}$.

Na podstawie myśli Wojtyły możemy wyróżnić kilka rodzajów potencjalności w zależności od funkcji, jaką spełnia, lub w zależności od poziomu, z jakim jest związana:

- emotywna (miejsce schronienia dla treści wypchniętych ze świadomości oraz woli) $)^{55}$,

- somatyczno-wegetatywna (organizm) ${ }^{56}$,

- psycho-emotywna (psychika) ${ }^{57}$,

- poznawcza (zdolność świadomości do poznawania) ${ }^{58}$,

- podmiotu osobowego (świadomość siebie) ${ }^{59}$,

- woli (aktów intencjonalnych) ${ }^{60}$.

Świadomość organizmu i jego funkcjonowania ogranicza się u człowieka wielokrotnie do świadomości posiadania ciała. Nie jesteśmy w stanie poznać poszczególnych aktów wegetatywnych, a nawet tzw. czucia cielesne nie są do końca świadome ${ }^{61}$.

Jasne staje się teraz to, że jedność dynamiczna podmiotu, jakim jest człowiek, urzeczywistnia się często bez udziału świadomości. Dostrzegamy też, że potencjalność jest uprzednia w stosunku do aktywności, ponieważ człowiek (osoba) jest najpierw jednością życia, a dopiero wtórnie przeżycia ${ }^{62}$.

Wojtyła nie omija w swych analizach także nośnego współcześnie w psychologii i kulturze pojęcia podświadomości. Twierdzi, iż w podświadomości gromadzą się treści przeżyć człowieka, które są zasadniczo różne od tych już uświadomionych lub też zostały ze świadomości wyparte. Jest to miejsce, gdzie sytuuje się zwykle instynkty oraz popędy, z którymi spotykamy się w czasie fenomenologicznej analizy człowieka.

Miejscem, gdzie gromadzą się treści zepchnięte ze świadomości, jest potencjalność wegetatywna oraz emotywna. Próg świadomości treści te przekraczają zwykle w sposób spontaniczny i niekontrolowany, a ewentualną kontrolę nad tym progiem posiada potencjalność nadrzędna ${ }^{63}$.

${ }^{54}$ Tenże, Osoba i czyn, s. 137.

${ }^{55}$ Tamże.

${ }^{56}$ Tamże, s. 145.

${ }^{57}$ Tamże, s. 146.

${ }^{58}$ Tamże, s. 84.

${ }^{59}$ Tamże, s. 86. Por. K. Wojtyła, Osoba: podmiot i wspólnota, s. 412.

${ }^{60}$ Tenże, Transcendencja osoby w czynie a autoteleologia człowieka, w: tenże, Osoba i czyn, s. 482. Por. tenże, Uczestnictwo czy alienacja?, w: tamże, s. 449.

${ }^{61}$ K. Wojtyła, Osoba i czyn, s. 137.

${ }^{62}$ Tamże, s. 139.

${ }^{63}$ Tamże, s. 140nn. 
Istnienie podświadomości w połączeniu ze świadomością wskazuje na ciągłość historii człowieka. Sama zaś podświadomość dąży do wypchnięcia swych treści w kierunku świadomości ${ }^{64}$.

Problematyką podświadomości zajmuje się szerzej psychoanaliza, którą zapoczątkował Z. Freud, oraz pochodne kierunki psychodynamiczne. Szerokie rozważenie tego zjawiska wykracza poza ramy tej pracy. Wypada jednak zaznaczyć, że Wojtyła nie pomija tego tematu, a wynika to ze stosowanej przez niego metody fenomenologicznej.

\section{FIERI}

Stawanie się (fieri) to dzianie się lub działanie skierowane ku podmiotowi, które go przekształca. Możemy w sposób pewny stwierdzić, że pierwszym fieri człowieka jest jego esse $e^{65}$ - fieri sequitur esse.

Po esse przychodzi kolej na operari - wtedy coś zaczyna istnieć w człowieku (na zasadzie przypadłości). To zaś zakłada, że człowiek jest kimś w możności (in potentia) i tę możność dopiero aktualizuje ${ }^{66}$.

Fieri człowieka jest wewnętrznie zróżnicowane:

- in fieri - (sfera somatyczno-wegetatywna) ma miejsce przez całe życie człowieka,

- fieri - rozwój psychiczny (psycho-emotywny) mamy tu do czynienia z pewną biernością,

- działania świadome - (in statu fieri67) sprawczość osobowa: staję się „kimś” oraz ,jjakimś" pod względem moralnym - tzn. dobrym lub złym ${ }^{68}$.

Człowiek jest osobą od momentu poczęcia poprzez samo zaistnienie, natomiast działanie w pełni ludzkie pojawia się stopniowo. Pierwiastek duchowy zadomawia się z czasem w kolejnych warstwach człowieczeństwa: somatycznej i psychicznej ${ }^{69}$.

Doświadczenie pokazuje jednak, że człowiek nie zawsze ujawnia cechy podmiotu lub ujawnia je tylko częściowo ${ }^{70}$. Niepełnosprawni umysłowo, częściowo upośledzeni są osobami w pełnym słowa tego znaczeniu, choć nie zawsze wykazują działania w pełni osobowe $\mathrm{e}^{71}$.

${ }^{64}$ Tamże, s. 143.

65 Tamże, s. 144.

${ }^{66}$ K. Wojtyła, Konstytuowanie się kultury poprzez ludzka praxis, Roczniki Filozoficzne 1979 , t. 27, z. 1, s. 12.

${ }^{67}$ M. Jędraszewski, Filozofia i modlitwa, s. 203.

${ }^{68}$ K. Wojtyła, Osoba i czyn, s. 145.

${ }^{69}$ Tenże, Osoba: podmiot $i$ wspólnota, s. 380.

${ }^{70}$ J. Galarowicz, Człowiek jest osobq, s. 189.

${ }^{71}$ Tenże, Imię wtasne człowieka, s. 131. 
Przez działanie w pełni świadome człowiek staje się twórcą samego siebie: „W pojęciu samostanowienia zawiera się więcej niż w pojęciu sprawczości: człowiek nie tylko jest sprawcą swoich czynów, ale przez te czyny jest zarazem w jakiś sposób 'twórcą siebie samego'. Działaniu towarzyszy stawanie się - co więcej, jest ono z nim organicznie zespolone"72. Jest to działanie naturalne i oczywiste dla człowieka.

Wojtyła pisze o tym w innym miejscu w następujący sposób: "Człowiek przez działanie kształtuje przede wszystkim siebie samego"73. Poprzez wolność, sprawczość człowieka staje się samostanowieniem ${ }^{74}$ i sprawia, że człowiek jest nie tylko sprawca, ale i twórcą czynów, które inicjuje i wykonuje, a przez nie staje się (fieri) w aspekcie moralnym ${ }^{75}$. Na tym także polega przeżycie etyczne ${ }^{76}$.

„Struktura czynu ludzkiego jest w szczególnym wymiarze auto-teleologiczna"77, ponieważ człowiek, odnosząc się do różnych przedmiotów i wybierając różne wartości, nie może jednocześnie nie zwracać się do siebie samego jako celu (tworzywa) i w jakiś sposób nie określać siebie (stawać się). Jądrem teorii samostanowienia jest fakt, że człowiek jest bytem samostwarzającym się poprzez swe czyny pod względem moralnym ${ }^{78}$. A co za tym idzie, „człowiek stanowi nie tylko o swoim działaniu, ale także stanowi o sobie w aspekcie najbardziej istotnej jakości. W ten sposób samostanowieniu odpowiada stawanie się człowieka jako człowieka. (Dzięki niemu staje się on coraz bardziej 'kimś' w znaczeniu osobowo-etycznym, skoro w znaczeniu ontycznym jest 'kimś' już od samego początku. Dodajmy w tym miejscu, że polski zaimek 'ktoś' jako przeciwieństwo zaimka 'coś' najkrócej ujmuje osobową odrębność człowieka)"779. Proces ten możemy ująć następująco:

czynię moje "ja" jakimś = staję się kimś (fieri).

Wynika stąd jasno, że wartości moralne są związane z osobą i z niej czerpią też swą realność. Dochodzimy tu też powoli do fenomenologicznego ujęcia wolności, która jawi się jako korzeń stawania się człowieka - czyli całej ludzkiej moralności. Wraz ze sprawczością pozwala ona stawać się człowiekowi dobrym lub złym ${ }^{80}$ - czyli ujawnia samostanowienie.

${ }^{72}$ K. Wojtyła, Osobowa struktura samostanowienia, s. 427n.

${ }^{73}$ Tenże, Osoba i czyn, s. 120.

${ }^{74}$ M. Jędraszewski, Filozofia i modlitwa, s. 203.

${ }^{75}$ J. Galarowicz, Człowiek jest osobq, s. 197. Por. K. Wojtyła, Osoba i czyn, s. 147.

${ }^{76} \mathrm{~K}$. Wojtyła, Zagadnienie woli w analizie aktu etycznego, w: tenże, Zagadnienie podmiotu moralności, Lublin 1991, s. 199.

77 Tenże, Osoba: podmiot $i$ wspólnota, s. 385.

${ }^{78}$ J. Galarowicz, Człowiek jest osobq, s. 199.

${ }^{79} \mathrm{~K}$. Wojtyła, Osobowa struktura samostanowienia, s. 428.

${ }^{80}$ Tenże, Osoba $i$ czyn, s. 147. 
Wolność decyduje o przeżyciu sprawczości i oddziela je od tego, co się tylko dzieje w człowieku ${ }^{81}$, autonomia woli zaś oznacza jej wolność właśnie w sensie pozytywnym ${ }^{82}$. W przypadku braku wolności trudno też mówić o sprawczości oraz o dynamicznej transcendencji, która na wolności się opiera ${ }^{83}$.

Stawanie się dokonuje się najpełniej przez akty samostanowienia: „Człowiek jest więc istotą zdolną do autokreacji w tym sensie, iż korzystając ze struktury samostanowienia, aktualizuje ją, a tym samym umacnia i pomaga się jej w pełni rozwinąć"

Nie można jednak zapominać o tym, że człowiek nie stwarza siebie w sensie absolutnym, ponieważ otrzymuje swój ontologiczny wymiar osobowy w darze. Człowiek zatem raczej współtworzy siebie i taka jest właściwie jego rola $\mathrm{w}$ spełnianiu siebie ${ }^{85}$. Jest on osobą:

- ontologicznie (metafizycznie) - jest darem sam dla siebie,

- faktycznie (potencjalnie) - staje się nią stopniowo ${ }^{86}$.

Potencjalność faktycznego bycia osobą wymaga od człowieka twórczej współpracy. Stawanie się osobą (fieri) jest pewnym trudem, który człowiek powinien podjać na drodze swego życia, aby faktycznie spełnić się w swym człowieczeństwie osobowym: „...ja występuje jako podmiot kształtujący - i to odpowiada jak najbardziej rzeczywistości osoby, którą jest każdy i każda z was"187.

Podsumowując, stawanie się człowieka moglibyśmy streścić w następujący sposób:

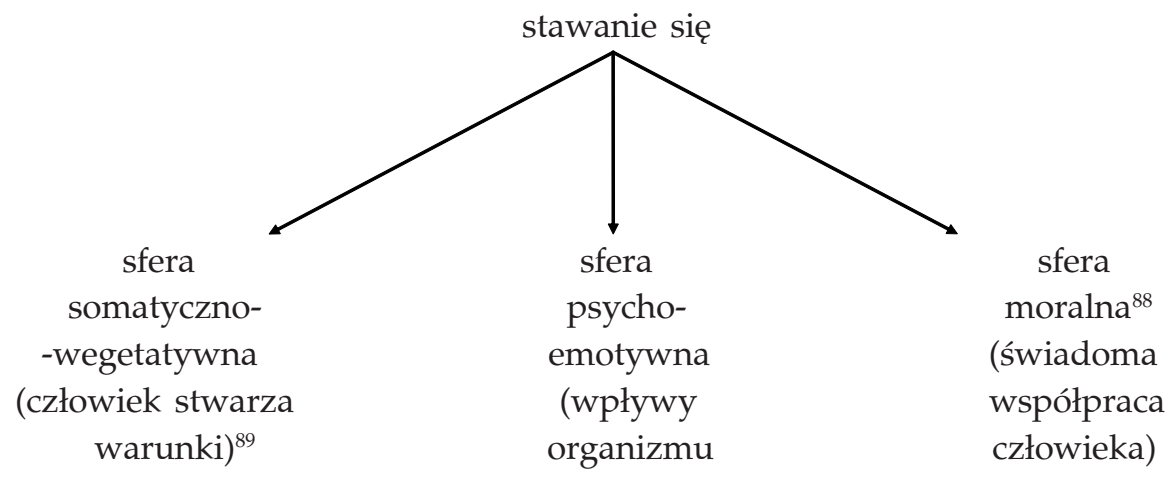

${ }^{81}$ Tamże, s. 148. Por. J. Galarowicz, Imię własne człowieka, s. 126.

${ }^{82} \mathrm{~K}$. Wojtyła, Akt i przeżycie etyczne, s. 46.

${ }^{83}$ Tenże, Osoba $i$ czyn, s. 149.

${ }^{84}$ J. Galarowicz, Człowiek jest osoba, s. 201.

${ }^{85}$ Por. tenże, Imię własne człowieka, s. 132n.

${ }^{86}$ Por. tamże, s. 136.

${ }^{87}$ Jan Paweł II, List Apostolski do młodych catego świata z okazji Międzynarodowego Roku Młodzieży, w: tenże, Listy do młodzieży, Poznań 1991, s. 37.

${ }^{88}$ A. Póltawski, Epistemologiczne podstawy, s. 104.

${ }^{89} \mathrm{~J}$. Galarowicz, Imie własne człowieka, s. 133. 
Stawanie się ma za cel spełnienie się i jest to punkt dojścia dla fieri:

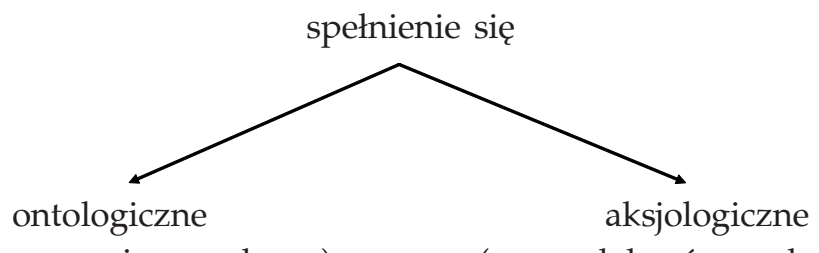

(w czynie w sensie moralnym)

(przez dobroć moralną czynu) ${ }^{90}$

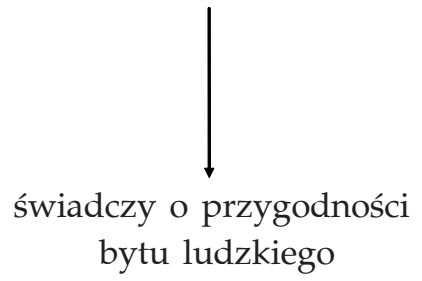

bytu ludzkiego

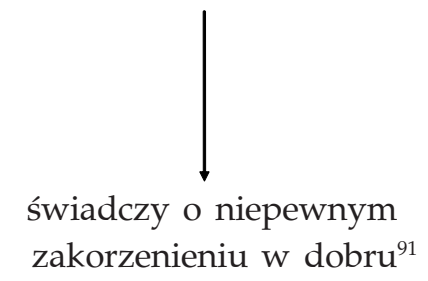

\section{ZAKOŃCZENIE}

Kardynał Karol Wojtyła, korzystając z filozofii klasycznej, jak również fenomenologii, rozwinął dynamiczną koncepcję człowieka jako bytu in statu fieri. Dla Wojtyły człowiek to istota głęboko autoteleologiczna92 ${ }^{92}$ która może spełnić się ostatecznie jedynie poprzez drugich, przez przekraczanie siebie ku innym, przez przerastanie siebie, a to zakłada zarówno wolność, jak i odpowiedzialność.

Wojtyła ukazuje dwa dynamizmy w człowieku: uczynnienia oraz działania świadome. Oba dynamizmy są jednak połączone jednym aktem istnienia, wspólnym suppositum, dzięki czemu nawet uczynnienia uzyskują charakter osobowy. Człowiek najpierw jest, a potem dopiero działa. To jego istnienie jest darem, a stawanie się w pełni osobą najważniejszym życiowym zadaniem. Jest to realistyczna wizja człowieka jako osoby. Pewne wątpliwości budzi tylko ujmowanie człowieka jako złożonego z natury i osoby. Klasyczne ujęcie ukazuje człowieka jako osobę, która stanowi zarówno rację działań człowieka, jak i rację samego człowieczeństwa.

Język antropologii Wojtyły pozostaje czasem w pewnym zawieszeniu między opisem fenomenologicznym a terminologią filozofii klasycznej, a przez to przynajmniej niektóre tezy są raczej analizą sposobu wypowiadania się o człowieku, niż analizą samego faktu człowieka ${ }^{93}$.

\footnotetext{
${ }^{90}$ K. Wojtyła, Osoba i czyn, s. 195nn. Por. J. Galarowicz, Imię własne człowieka, s. 122.

${ }^{91}$ Tamże, s. 198. Por. J. Galarowicz, Imie wtasne człowieka, s. 139.

${ }_{92}$ Por. K. Wojtyła, Transcendencja osoby, s. 488.

${ }_{93}$ Z. Mikołajko, Problem osoby - tradycja i zmiana, Studia Religioznawcze 1983, t. 17, s. 89.
} 
Istnieją oczywiście także pewne punkty, w których antropologia Wojtyły może być dalej doprecyzowywana. Bardzo owocne mogłoby być podjęcie bardzo ważnej intuicji wyrażonej, lecz właściwie nierozwiniętej w dziele Osoba $i$ czyn. Chodzi mianowicie o ukazanie pierwszeństwa istnienia przed działaniem osobowym. Teza, że każdego człowieka zapoczątkowuje akt istnienia, który w swej istocie jest osobowy oraz przygodny, ma wielką wartość dla antropologii filozoficznej. Innym ciekawym zagadnieniem wartym dalszych badań może być zapoczątkowana przez Wojtyłę analiza relacji między człowiekiem a osobą - wyrażając się językiem filozofa - analiza działań świadomych oraz nieświadomej pracy organizmu człowieka.

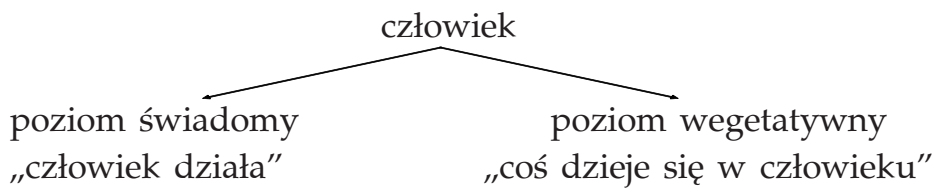

$(\text { czyn człowieka) })^{94}$ aktywność agere $^{95}$ interioryzacja przez świadomość 96

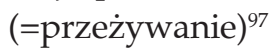
centrum osobowe $\mathrm{e}^{99}$

$$
\begin{gathered}
\text { „ktoś"100 } \\
\text {,ja" }
\end{gathered}
$$

szczęśliwość - rozpacz "chcę"103

doświadczenie sprawczości ${ }^{105}$

bierność
pati
nieświadomość
podświadomość ${ }^{98}$
powierzchowne warstwy człowieka
",coś"
ciało/psychika ${ }^{101}$
przyjemność - przykrość102
"chce mi się"
(zachcenie) ${ }^{104}$
jej brak

ernośc nieświadomość

podświadomość ${ }^{98}$<smiles>C[AsH2]</smiles>

ciało/psychika ${ }^{101}$

"chce mi się"

jej brak

${ }^{94}$ K. Wojtyła, Osoba i czyn, s. 68.

95 Tamże, s. 111nn., 438n.

${ }^{96}$ Por. tamże, s. 101.

${ }^{97}$ K. Wojtyła, Osoba: podmiot i wspólnota, s. 382. Por. K. Wojtyła, System etyczny Maxa Schelera jako środek do opracowania etyki chrześcijańskiej, w: tenże, Zagadnienie podmiotu moralności, s. 137.

98 Tenże, Osoba i czyn, s. 138. Por. T. Styczeń, Metoda antropologii filozoficznej w "Osobie i czynie", Analecta Cracoviensia 1973-1974, t. 5-6, s. 111.

${ }^{99}$ K. Wojtyła, Osoba: podmiot $i$ wspólnota, s. 379.

100 Tenże, Osobowa struktura samostanowienia, s. 430.

${ }^{101} \mathrm{~J}$. Galarowicz, Imię wtasne człowieka, s. 125.

${ }^{102}$ K. Wojtyła, Osoba $i$ czyn, s. 219.

${ }^{103}$ Por. tenże, Osobowa struktura samostanowienia, s. 427.

${ }^{104}$ Por. J. Galarowicz, Imię wtasne człowieka, s. 149.

105 Por. tamże, s. 125. 
Współcześnie obserwujemy bardzo dynamiczny rozwój nauk społecznych, których przedmiotem zainteresowania jest człowiek zanurzony w swych rozmaitych kontekstach bycia i działania, natomiast nie wygląda na to, żeby antropologia filozoficzna cieszyła się równie wielkim zainteresowaniem. Propozycja połączenia filozofii klasycznej oraz fenomenologii, która jest bliska współczesnej psychologii czy socjologii, wydaje się ciekawą próbą budowania mostu między naukami o człowieku. Terminologia rozwijana przez Wojtyłę w wielu punktach jest bliska wyżej wymienionym dyscyplinom naukowym i mogłaby zostać wykorzystana do owocnego dialogu pomiędzy antropologią filozoficzną a innymi naukami, zajmującymi się tym samym przedmiotem materialnym, jakim jest człowiek. Mogłoby to zabezpieczyć adekwatne rozumienie człowieka jako osoby oraz przyczynić się do stałej ochrony jego osobowej godności.

\section{KARDINAL KAROL WOJTYŁA'S CONCEPT OF THE HUMAN BEING}

\section{SUMMARY}

The anthropology of Karol Wojtyła (John Paul II) is a unique synthesis of the classical approach to the understanding of the human person as a suppositum, a subject of any other characteristics, and a phenomenological description of human behavior. The key concepts for Wojtyła are self-direction and self-determination which he developed principally in his main anthropological work - The Acting Person. The core of human behavior is a reflective action by which he or she becomes a morally responsible being.

Wojtyła describes two levels of human action. The first is everything that occurs naturally. This he calls the vegetative level. The second is all that the human person does purposely or at least consciously. This is the level of experience. Both levels are united in the same human being, but only the second contributes to the moral development of the human person. The aim of this paper is to examine this vision of the human be. 